DOI: $10.1515 /$ rpp-2015-0056

Postgraduate student, ALEKSANDRA MICHALSKA

Khmelnytskyi National University, Ukraine

Address: 11 Instytutska St., Khmelnytskyi, 29016, Ukraine

E-mail: a.michalska24@gmail.com

\title{
HEALTH HABITS AND THEIR FORMATION AMONG TODAY'S YOUNG PEOPLE OF SCHOOL AGE IN POLAND
}

\begin{abstract}
This paper presents the impact of health education on life expectancy and adaption to modern conditions. The acquisition of healthy attitude in the first and second decade of life influences the development of trade, economic status and helps efficiently cope with stress. The article highlights the impact of "health literacy", the school environment and family upbringing and subsequent persistence in health. Organization of education should be started from childhood. Unfortunately many teachers and parents cannot supply information about sanitary education, correct sanitation, healthy nutrition and physical activity. Disciples who lack support and knowledge can be exposed under pressure of contemporary risky operations. Pediatric population makes up to $30 \%$ of the whole population. In the first and second decade of life the baby is shaped and strengthens previously instilled habits. Stage of puberty is the most favorable moment for proper physical development of young people. During this period perpetuate conscious health behaviors, but at the same time there are health risk behaviors. These behaviors affect the quality and duration in health. Measures of health policy on school-age children should be focused primarily on prevention and health promotion.
\end{abstract}

Key words: Polish youth, the dynamics of health problems, environment education, health education, injury, disorder, prophylaxis.

\section{INTRODUCTION}

Polish society guarantees health care, which includes the development and realization of the full potential of health as well as reducing morbidity and mortality. Health policy measures are targeted at young people and are focused on health promotion and education. Programs directed at the extension of the quality and length of life of Poles, have eliminated many infectious diseases, reduced mortality from cardiovascular diseases and minimized infant mortality. There is no doubt that the future of Poland and its place in Europe and in the world depends on the level of education, health, and the intellectual potential of the young generation.

In order to change the health situation of contemporary Polish youth were used, inter alia, data on demographics and socio-economic factors and the three priorities in caring for the child, i.e. natal care; reducing morbidity and combat child mortality and medical care for children and young people of school age; an analysis of the health situation of children and young people with regard to age groups. They addressed the basic conditions inadequate diet and low physical activity. There have been established appropriate objectives and activities (Szymborski, 2015).

\section{THE AIM OF THE STUDY}

The aim of the study is to present the most common health problems among young people of school age in Poland. 


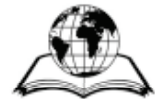

\section{THEORETICAL FRAMEWORK AND RESEARCH METHODS}

Theoretical framework of the paper is based on the research conducted by A. Bartoszek, M. Charzyńska-Gula, M. Czupryna, U. Fałdyga, K. Kocka, H. Kachaniuk, M. Malinowska-Cieślik.

Among the methods used in the study, we define, in particular, such as analysis, comparison, generalization. We also used the method of diagnostic survey: observation, interview, questionnaire, survey documents to measure the educational environment.

\section{RESULTS}

According to the HBSC's research $14 \%$ of young people fall on chronic diseases (most are respiratory system diseases).

In the European Union more children die from injuries than from all other diseases combined. There has been a significant socio-economic gradient prevalence and consequences of accidents among children at the expense of the poor. Only the prevention of posttraumatic effects significantly reduces mortality of children, attitudes to treatment without prevention, do not affect the decline in child mortality rates while increasing permanent disability (Korczak, 2005). The role of the Ministry of Health should be determined in coordinating the national policy for the protection and promotion of the health of children and young people and the creation of appropriate services that meet the needs of this group of the population (Ministerstwo Zdrowia, 2013).

On the basis of the tests screening and analysis of documentation and provided information on the health problems of children and adolescents have been carried out. Currently injuries are the major cause of younger population deaths. It has been reported that they represent $50 \%$ of all deaths of children and adolescents. For this reason, 12 per 100,000 children die.

Chronic post-traumatic cause of death among children and adolescents aged 5-14 years are traffic accidents (49\% is mainly pedestrian accident) and drowning (19\%) (Fig. 1) (Malinowska-Cieślik, Czupryna, 2002).

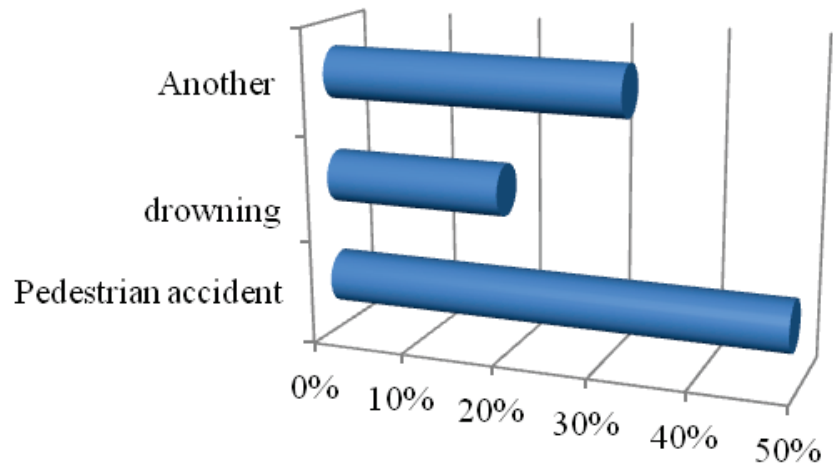

- The most common cause of traumatic death

Fig. 1. The most common cause of traumatic death

The dominant cause of hospitalization represents collapses up to $51 \%$ and traffic accidents $-21 \%$. Mortality rates and hospitalization of boys are higher than girls (Fig. 2) (Malinowska-Cieślik, Czupryna, 2002). 


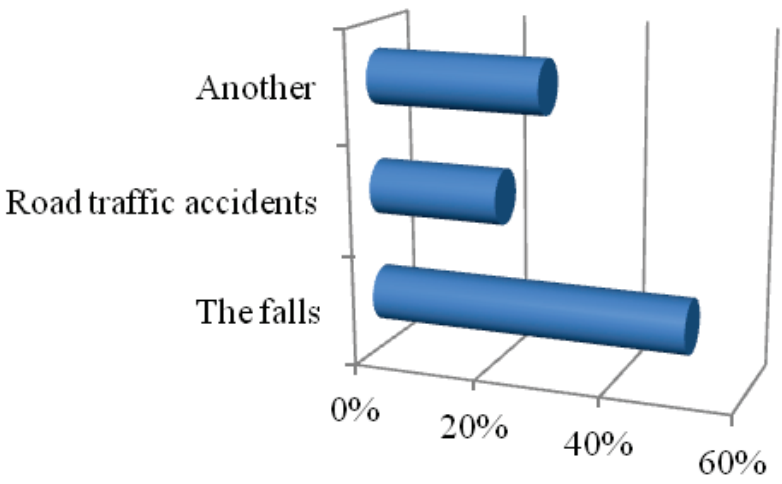

- The dominant cause of hospitalization

Fig. 2. The dominant cause of hospitalization

Accident mortality is higher in rural areas than in the city. It was also observed that higher rates of hospitalization are in the city than in the countryside (Fig 3) (MalinowskaCieślik, Czupryna, 2002).

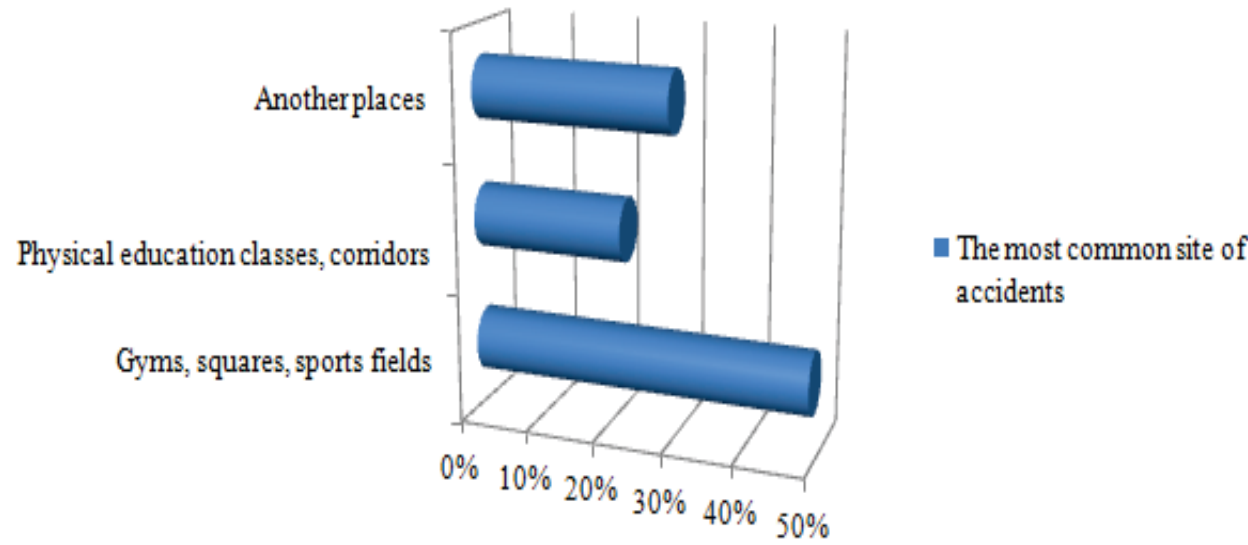

Fig. 3. The most common site of accidents

In addition, studies conducted in 1999/2000 prove that most fatal accidents occurred in primary schools, namely $59 \%$, in secondary schools - only $13 \%$. Significant accident rate of school was observed in Świętokrzyskie, Lubuskie, Zachodniopomorskie, Podlasie (every 10 child residing in elementary school had an accident). Permanent occurred fractures, dislocations and sprains, bruises, crushing, tearing and external wounds. Accidents occurred mostly at gyms, sports fields, playgrounds (49 \%), often during PE lessons and hallways during breaks $(22 \%)$.

Addiction. The chart below shows frequency of consumption of stimulants in the second decade of life (see Fig. 4) (Malinowska-Cieślik, Czupryna, 2002). 


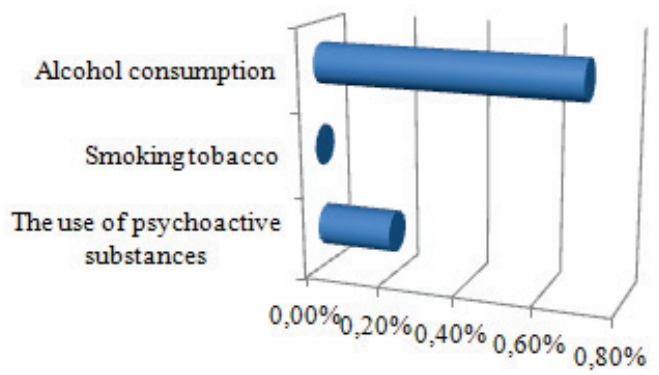

- Frequency of consumption of stimulants in the second decade oflife

Fig. 4. Frequency of consumption of stimulants in the second decade of life

Dangerous health risks prevalent especially among middle school students are addiction. Smoking cigarettes admitted in the 2008/2009 school year $-3.2 \%$ of young people, and in 2010/2011 - $11.3 \%$ of the students. Data analysis showed that a small number of young people are reaching for alcohol and drugs. In 2008/2009 admitted to this addiction respectively $0.7 \%$ and $0.2 \%$ of students, while in 2009/2010 and 2010/2011, none of the students reported this kind of problem.

In the second decade of life significantly increases the risk of taking actions that compromise health, i.e. smoking, drinking alcohol or psychoactive drugs intake. The conducted research shows that taking risky behavior by young people is conducive to lack of acceptance by peers, a sense of loneliness or inappropriate relationships with parents. It has been observed that a small percentage of young people, representing $0.7 \%$ admitting to drinking and use of psychoactive substances is $0.2 \%$. Smoking affects a considerably higher percentage of investigated up $11.3 \%$.

This situation is particularly alarming due to a number of health risks that smoking causes. Moreover, it demonstrates that early initiation of nicotine increases the risk of smoking addiction in the future (Malinowska-Cieślik, Czupryna, 2002).

Disturbances in the somatic development. Another common health problem spread among primary school pupils and middle school is the development of somatic disorders. They covered the following groups of people: $21.7 \%$ of children of primary school and $21.2 \%$ of middle school students in 2008/09, in 2009/10 respectively $19.2 \%$ and $14.9 \%$ of respondents, while $17.9 \%$ and $19.5 \%$ of children in 2010/2011. The chart below shows somatoform disorder (Fig. 5) (Malinowska-Cieślik, Czupryna, 2002).

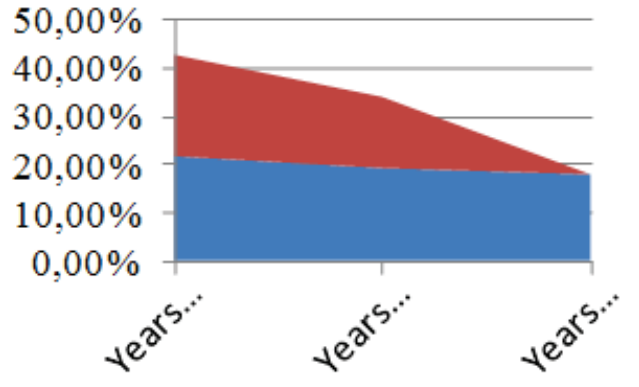

Fig. 5. Somatoform disorders
Middle school students

Elementary school students 
In this group of disorders dominated overweight and obesity, which was most often caused by nutritional mistakes and constantly decreasing physical activity of children and youth. A common, long-term (persisting more than 6 months) health problem diagnosed in primary school pupils and middle school were respiratory diseases. Involved in individual yearbooks $(2008 / 2009,2009 / 2010,2010 / 2011)$ the following numbers of respondents are $3.9 \%, 3.8 \%$ and $4.5 \%$ of primary school pupils and $6.2 \%, 4.5 \%$ and $7.6 \%$ of junior high school students. The most common respiratory diseases include various kinds of allergies and asthma. Tuberculosis was not noticed among children in school age. A serious health problem that affects children of school age is chronic diseases of hearing and speech organs. These disorders were involved in the school year $2008 / 2009-6.9 \%$ of primary school pupils and $1.15 \%$ of middle school students; in $2009 / 2010-2.3 \%$ of primary school pupils and $0.5 \%$ of middle school students; and in 2010/2011 - 3.8\% of children attending primary school and $0.6 \%$ of middle school students.

Less frequent health problems found in in school-age children include diseases and disorders of the cardiovascular system, central nervous system, chronic urinary tract infections or other conditions requiring active medical care, i.e. diabetes, thyroid disease and cancer.

Posture. The chart below shows: posture (Fig. 6) (Kocka, Kachaniuk, Bartoszek, Fałdyga, Charzyńska-Gula, 2013).

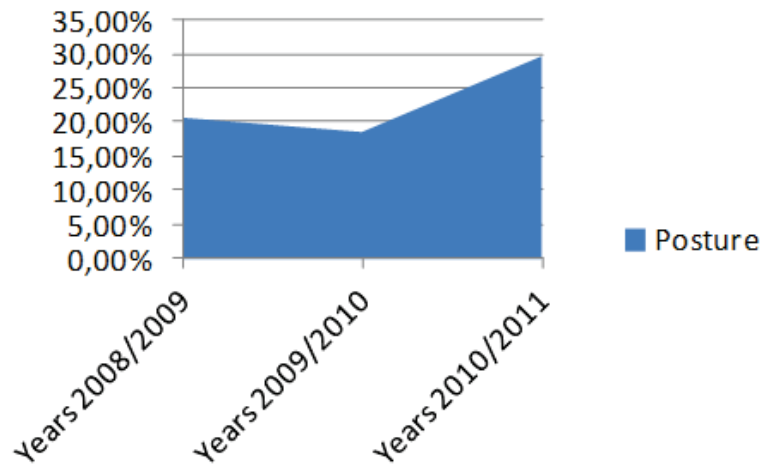

Fig. 6. Posture

Another major problem that young people of school age often struggle is defect attitude. It concerned in particular years: $20.7 \%$ of students in 2008/2009, $18.6 \%$ of the students in 2009/2010 and $29.7 \%$ of those surveyed in 2010/2011.

Among examined percentage of patients of static musculoskeletal disorders prevailed: valgus knees and feet flat-lopsided. Similarly, in 2010/11 especially considered health problem among junior high school students were static diseases and disorders of the musculoskeletal system. It was found that they concerned up to $24.6 \%$ of the population. Scoliosis was diagnosed in $5.4 \%$ and valgus knees and flat feet in $1.4 \%$ of the students. While the main emerging health disorder diagnosed in middle school students in 2008/09, $2009 / 10$ were defects and eye diseases. In 2008/2009 the problem affected $18.5 \%$ of the students; in 2009/2010 - $15.4 \%$, while in 2010/2011 - 22\% (Kocka, Kachaniuk, Bartoszek, Fałdyga, Charzyńska-Gula, 2013). 


\section{CONCLUSIONS}

The analysis reveals the most common health problems of contemporary Polish youth. Young people's health is subject to numerous factors. It depends primarily on health policy, medicine and education restorative health carers and socio-economic factors. Educational programs and science of preventive behaviors in the school environment in Poland consists of using life jackets, developing the skills of swimming, swimming only in designated areas, using seat belt while driving, wearing reflectors, science movement of pedestrians on the road, driving in bicycle helmets, proper lighting and marking bike. During sports activities, among others are the use of warm-up, coaching under the supervision of an instructor and the use of necessary safeguards.

During the development of the health strategy of children and adolescents the Member States should first create a data collection system based on programs covering health and development of children and adolescents, taking into account the prospects of their further life and immediately introduce measures aimed at solving major health problems of children and adolescents, defining the role of the Ministry of Health in the national policy for the protection and promotion of the health of children and youth and creation of appropriate services that meet the needs of this population group, create a system of data based on evidence, to develop cross-sectoral actions aimed at solving major health problems. In order to improve the health situation of contemporary Polish youth, caregivers and teachers who exercise the medical care of the student in an appropriate manner. This ensures appropriate cooperation of the persons responsible for the health of students.

\section{REFERENCES}

1. Kocka, K., Kachaniuk, H., Bartoszek, A. Fałdyga, U., Charzyńska-Gula, M. (2013). Najczęstsze problemy zdrowotne dzieci w wieku szkolnym - na przyktadzie szkoły podstawowej $i$ gimnazjum w Lublinie [The Most Common Health Problems of Children of School Age in Primary and Secondary Schools of Lublin]. Medycyna Ogólna i Nauki o Zdrowiu [General Medicine and Health Sciences], No 4, pp. 508-513 (in Polish).

2. Korczak, J. (2005). Prawo dziecka do zdrowia [Child's Right to Health]. Retrieved 20.08.2015 from : http://webcache.googleusercontent.com/search? $\mathrm{q}=$ cache:1UkA atRngy8J:www.pskorczak.org.pl/strony/stara_strona/strony/ochrona\%2520zdrowia\%2520d ziecka.ppt.ppt $+\& \mathrm{~cd}=2 \& \mathrm{hl}=\mathrm{pl} \& \mathrm{ct}=\mathrm{clnk} \& \mathrm{gl}=\mathrm{pl}$.

3. Malinowska-Cieślik, M., Czupryna, A. (2002). Wypadki i urazy dzieci $w$ wieku szkolnym. Zdrowie Publiczne [Accidents and Injuries of Children of School Age. Public health]. Volume 112 (4), pp. 505-510 (in Polish).

4. Ministerstwo zdrowia [Ministry of Health]. (2013). Zdrowie ucznia [Pupil's Health]. Retrieved 08.20.2015 from : http://www.mz.gov.pl/zdrowie-iprofilaktyka/zdrowie-matki-i-dziecka/zdrowie-ucznia.

5. Szymborski, J. (2015). Sytuacja zdrowotna dzieci w Polsce - aktualne problemy $i$ propozycje rozwiazań systemowych [The Health Situation of Children in Poland - Current Problems and Proposed Solutions of System]. Retrieved 20.08.2015 from : http://brpd.gov. pl/aktualnosci/sytuacja-zdrowotna-dzieci-w-polsce-aktualne-problemy-i-propozycje-rozwiazansystemowych.

6. Woynarowska, B. (2005). Europejska strategia na rzecz zdrowia i rozwoju dzieci $i$ mtodzieży [The European Strategy for Health and Development of Children and Youth]. Retrieved 20.08.2015 from : www.lider.szs.pl/biblioteka/download.php?plik_id=10 33\&f=artykul_1033.doc. 